\title{
Adenocarcinoma of the urinary bladder with inferior vena cava thrombus
}

\author{
Harkirat Singh Talwar, Vikas Kumar Panwar
}

Urology, All India Institute of Medical Sciences-Rishikesh, Rishikesh, India

Correspondence to Dr Vikas Kumar Panwar; vikaspanwar.dr@gmail.com

Accepted 18 October 2020

Check for updates

(c) BMJ Publishing Group Limited 2020. No commercial re-use. See rights and permissions. Published by BMJ.

\begin{tabular}{|l|}
\hline To cite: Talwar HS, \\
Panwar VK. BMJ Case \\
Rep 2020;13:e237772. \\
doi:10.1136/bcr-2020- \\
237772 \\
\hline
\end{tabular}

\section{DESCRIPTION}

Adenocarcinoma of the bladder is an unusual malignancy arising most commonly from the dome and posterior wall of the bladder. It has a male predominance seen during the sixth and seventh decade. ${ }^{1}$ It arises from the urothelium although has a pure glandular histology. ${ }^{2}$ Haematuria is the most common presenting symptom and various cystoscopic morphologies exist like solid, papillary, sessile or ulcerated. Notable risk factors for adenocarcinoma include schistosomiasis, chronic irritation, cystocoele and exstrophy bladder. Adenocarcinoma of the bladder may be primary in origin or may be secondary to involvement by adjacent organs. Urachal adenocarcinoma although a separate entity is frequently grouped with bladder adenocarcinoma. No case has been ever reported in the literature of a bladder carcinoma with inferior vena cava (IVC) thrombus. This is a first case of its kind to be reported with tumour extending through the iliac veins into the IVC.

A 60-year-old man presented with haematuria and history of transurethral resection of bladder mass done elsewhere. General and physical examination revealed no positive findings and he had a poor performance status. Histopathology was suggestive of adenocarcinoma of the urinary bladder with tumour infiltrating the deep muscle. Contrast enhanced CT scan revealed $7.2 \times 6.5 \mathrm{~cm}$ mass arising from the dome and the right posterolateral wall of the urinary bladder and extending into right ureter for a length of $3.5 \mathrm{~cm}$ causing gross hydroureteronephrosis (figure 1). The mass was seen extending into the small bowel mesentery and the mesorectal fascia and seminal vesicles. An enhancing tumour thrombus was also seen for a length of $5.2 \mathrm{~cm}$ in the distal IVC extending into bilateral common iliac veins and the

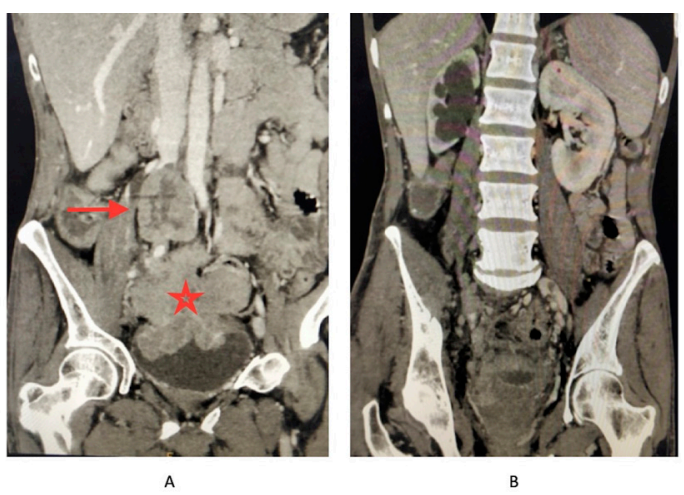

Figure 1 Coronal sections showing the bladder mass and the inferior vena cava thrombus $(A)$ and the upstream right hydroureteronephrosis as a result of the bladder mass and right ureteric extension (B).

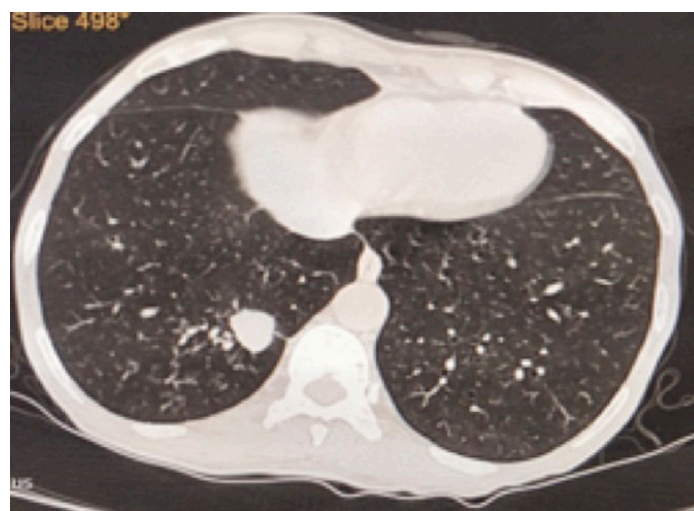

Figure 2 Axial section of the thorax revealing multiple parenchymal pulmonary metastatic deposits.

right internal and external iliac veins. Metastatic work up revealed extensive lesions in the lungs and the skeleton (figure 2). Creatinine clearance of the patient improved to $70 \mathrm{~mL} / \mathrm{min}$ post insertion of the nephrostomy tube. The patient was started on lowmolecular weight heparin and also received palliative chemotherapy. The patient succumbed to illness 3 months after presentation.

Prevention of pulmonary embolism is of utmost priority in such patients with anticoagulation and IVC filter being the mainstay. ${ }^{3}$ Although low-molecular weight heparin is preferred with total/near total tumour thrombus or those with a bland thrombus, IVC filter may be required in patients when anticoagulation fails or is contraindicated. Treatment of the malignancy according to standard guidelines is mandated thereafter. ${ }^{4}$ Radical cystectomy and pelvic lymph node dissection remains the standard of care for localised disease as chemotherapy has not shown to improve outcomes in adenocarcinoma of bladder. Platinum-based chemotherapy regimens

\section{Learning points}

- Primary adenocarcinomas of the urinary bladder are rare tumours and are usually detected at an advanced stage and thus have poor prognosis.

- Bladder cancers can present with inferior vena cava (IVC) thrombus with a possible route being through the internal and common iliac veins. This is the first case to be reported of a bladder carcinoma with IVC thrombus.

- Anticoagulation and prevention of pulmonary embolism remains the top priority in such cases followed by stage-based management following standard guidelines. 
used against urothelial carcinoma are not effective against adenocarcinoma. Majority of patients have muscle invasive disease at presentation and prognosis remains poor with adenocarcinoma of urinary bladder having a poorer stage by stage survival outcome as compared with its urothelial counterpart.

Contributors HST: Data collection and manuscript writing. VKP: Manuscript editing and final validation.

Funding The authors have not declared a specific grant for this research from any funding agency in the public, commercial or not-for-profit sectors.

Competing interests None declared.
Patient consent for publication Obtained.

Provenance and peer review Not commissioned; externally peer reviewed.

\section{REFERENCES}

1 Dadhania V, Czerniak B, Guo CC. Adenocarcinoma of the urinary bladder. Am I Clin Exp Urol 2015:3:51-63.

2 Grignon DJ, Ro JY, Ayala AG, et al. Primary adenocarcinoma of the urinary bladder. A clinicopathologic analysis of 72 cases. Cancer 1991;67:2165-72.

3 Pandhi MB, Desai KR, Ryu RK, et al. The role of inferior vena cava filters in cancer patients. Semin Intervent Radiol 2016;33:071-4.

4 Black PC, Brown GA, Dinney CPN. The impact of variant histology on the outcome of bladder cancer treated with curative intent. Urol Oncol 2009;27:3-7.

Copyright 2020 BMJ Publishing Group. All rights reserved. For permission to reuse any of this content visit

https://www.bmj.com/company/products-services/rights-and-licensing/permissions/

BMJ Case Report Fellows may re-use this article for personal use and teaching without any further permission.

Become a Fellow of BMJ Case Reports today and you can:

- Submit as many cases as you like

Enjoy fast sympathetic peer review and rapid publication of accepted articles

Access all the published articles

Re-use any of the published material for personal use and teaching without further permission

\section{Customer Service}

If you have any further queries about your subscription, please contact our customer services team on +44 (0) 2071111105 or via email at support@bmj.com.

Visit casereports.bmj.com for more articles like this and to become a Fellow 